\title{
Chemical and biological attributes of a lowland soil affected by land leveling
}

\author{
José Maria Barbat Parfitt(1), Luís Carlos Timm²), Klaus Reichardt(3), Luiz Fernando Spinelli Pinto ${ }^{(4)}$, \\ Eloy Antonio Pauletto(4) and Danilo Dufech Castilhos ${ }^{(4)}$
}

\begin{abstract}
(1)Embrapa Clima Temperado, BR 392, Km 78, CEP 96001-970 Pelotas, RS, Brazil. E-mail: jose.parfitt@embrapa.br (2)Universidade Federal de Pelotas, Departamento de Engenharia Rural, Campus Universitário, s/no, Caixa Postal 354, CEP 96010-900 Pelotas, RS, Brazil. E-mail: Ictimm@ufpel.edu.br ${ }^{(3)}$ Universidade de São Paulo, Centro de Energia Nuclear na Agricultura, Laboratório de Física do Solo, Caixa Postal 96, CEP 13418-900 Piracicaba, SP, Brazil. E-mail: klaus@cena.usp.br (4)Universidade Federal de Pelotas, Departamento de Ciência do Solo, Campus Universitário, s/nº, Caixa Postal 354, CEP 96010-900 Pelotas, RS, Brazil. E-mail: Ifspin@ufpel.tche.br, pauletto_sul@yahoo.com.br, danilodc@ufpel.edu.br
\end{abstract}

Abstract - The objective of this work was to evaluate the relationship between soil chemical and biological attributes and the magnitude of cuts and fills after the land leveling process of a lowland soil. Soil samples were collected from the $0-0.20 \mathrm{~m}$ layer, before and after leveling, on a 100 point grid established in the experimental area, to evaluate chemical attributes and soil microbial biomass carbon (MBC). Leveling operations altered the magnitude of soil chemical and biological attributes. Values of $\mathrm{Ca}, \mathrm{Mg}, \mathrm{S}$, cation exchange capacity, $\mathrm{Mn}$, $\mathrm{P}, \mathrm{Zn}$, and soil organic matter (SOM) decreased in the soil profile, whereas $\mathrm{Al}, \mathrm{K}$, and $\mathrm{MBC}$ increased after leveling. Land leveling decreased in $20 \%$ SOM average content in the $0-0.20 \mathrm{~m}$ layer. The great majority of the chemical attributes did not show relations between their values and the magnitude of cuts and fills. The relation was quadratic for SOM, $\mathrm{P}$, and total $\mathrm{N}$, and was linear for $\mathrm{K}$, showing a positive slope and indicating increase in the magnitude of these attributes in cut areas and stability in fill areas. The relationships between these chemical attributes and the magnitude of cuts and fills indicate that the land leveling map may be a useful tool for degraded soil recuperation through amendments and organic fertilizers.

Index terms: flooded rice, soil biological attributes, soil chemical attributes, soil management, soil movement.

\section{Atributos químicos e biológicos de um solo de várzea afetados pela sistematização do terreno}

\begin{abstract}
Resumo - O objetivo deste trabalho foi avaliar a relação entre os atributos químicos e biológicos do solo e as magnitudes de cortes e aterros após sistematização de um solo de várzea. Foram coletadas amostras de solo na camada de $0-0,20 \mathrm{~m}$, antes e depois da sistematização, em uma malha de 100 pontos estabelecida na área experimental, para avaliar os atributos químicos do solo e o carbono da biomassa microbiana (CBM). A sistematização alterou a magnitude dos atributos químicos e biológicos do solo. Valores de $\mathrm{Ca}, \mathrm{Mg}, \mathrm{S}$, capacidade de troca catiônica, Mn, P, Zn e matéria orgânica do solo (MOS) diminuíram no perfil do solo, enquanto os de Al, K e CBM aumentaram após a sistematização. A sistematização reduziu em $20 \%$ o conteúdo médio de MOS na camada de 0-0,20 m. A maior parte dos atributos químicos não apresentou relação com as magnitudes de corte e aterro. A relação foi quadrática para MOS, P e N total, e linear para $\mathrm{K}$, mostrando inclinação positiva e aumento das magnitudes destes atributos em áreas de corte e estabilidade em áreas de aterro. As relações entre estes atributos químicos e as magnitudes de cortes e aterro indicam que o mapa de sistematização pode ser uma ferramenta útil para a recuperação de solos degradados por meio da aplicação de corretivos e fertilizantes orgânicos.
\end{abstract}

Termos para indexação: arroz irrigado, atributos biológicos do solo, atributos químicos do solo, manejo do solo, movimento do solo.

\section{Introduction}

Land leveling is used to flatten the soil surface to facilitate the distribution of irrigation and also to improve land conditions for several agricultural practices that are best performed on leveled soil.
According to the last Censo da lavoura de arroz irrigado do Rio Grande do Sul - safra 2004/2005 (2006) survey, in the 1999/2000 agronomic year, the land-leveled area in the state of Rio Grande do Sul, Brazil, was estimated to be around 150,000 ha of a total of 5,400,000 ha, which comprise almost the total 
lowland area of this state (Pinto et al., 2004). However, not all lowland areas are potentially leveled because some of them show irregular microtopography despite being classified as flat areas.

Due to cuts made at higher elevations, leveling can cause a significant decrease in the A horizon thickness with possible exposure of subsoil layers. Examining the effects of land leveling on the yield of vineyards in the Penedès region, Northeastern Spain, Ramos \& Martínez-Casasnovas (2010) found positive differences in yield of $28 \%$ between leveled and non-leveled areas under similar management practices. Still in the Penedès region, Martínez-Casasnovas \& Ramos (2009) also analyzed the changes in soil properties caused by erosion, deep ploughing, and land leveling. They concluded that land leveling and the resultant increase in erosion altered soil properties and could contribute to global warming by depleting the soil of organic matter. In Arkansas, USA, Brye (2006) characterized land leveling impacts on the magnitude, variance, and spatial distributions of chemical soil properties of a Sharkey clay soil (very fine, smectitic, thermic Chromic Epiaquert) used for irrigated rice (Oryza sativa L.) and soybean [Glycine max (L.) Merr.] crops. The author found that land leveling affected the magnitude of all evaluated properties. Soil $\mathrm{pH}$, electrical conductivity, extractable potassium, calcium, magnesium, sodium, sulfur, iron, and copper increased in the $0-0.10 \mathrm{~m}$ layer, whereas soil organic matter (OM) content, soil total nitrogen (TN) concentration, $\mathrm{C} / \mathrm{N}$ ratio, extractable phosphorus, and manganese contents decreased after leveling. Brye (2006) also reported that the variance associated with soil $\mathrm{pH}$ and Mehlich-3 extractable $\mathrm{P}, \mathrm{K}, \mathrm{Na}, \mathrm{S}, \mathrm{Mn}, \mathrm{Cu}$, and $\mathrm{Zn}$ contents decreased with land leveling, which also changed the spatial distribution of all chemical properties. Reichert et al. (2008), in a study carried out in Brazil, verified that land leveling increased the spatial variability of soil chemical attributes of a Planossolo Hidromórfico Distrófico típico (Typic Albaqualf), which was reflected in the productivity of a soybean crop. However, the authors did not point out which of the attributes were the most affected by the leveling practice.

Other studies have been carried out to evaluate leveling effects on the magnitude and spatial distribution of soil attributes (Brye et al., 2004; Ramos \& Martínez-Casasnovas, 2006). Many benefits are associated with the land leveling practice (Ramos et al., 2007); however, studies have also pointed to some disadvantages due to severe soil disturbance, indicating that there is some controversy regarding the positive and negative effects of leveling (Walker et al., 2003; Brye et al., 2005; Cay \& Cattle, 2005). Therefore, new studies are necessary to investigate the subject, establishing parameters that may help farmers when planning land leveling, in the sense of foreseeing changes that will occur in the area. Published reports do not associate changes in soil characteristics on cut areas, because the soil from these areas will cover the fill areas and those will be exposed at the surface after the leveling operation. No association has been made between the changes in soil attributes and the magnitude of cuts and fills in order to evaluate which soil attributes are most affected by the leveling process.

The objective of this work was to evaluate the relationship between soil chemical and biological attributes and the magnitude of cuts and fills after the land leveling process of a lowland soil.

\section{Materials and Methods}

The study was carried out on a 0.81 ha area of the municipality of Capão do Leão, state of Rio Grande

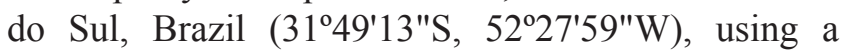
grid of 100 georeferenced points spaced $10 \mathrm{~m}$ apart in orthogonal directions for sampling. The climate in the region is of the Cfa type, according to Köppen classification (Köppen, 1931), and the specific area is representative of a subtropical marine environment with a sub-humid summer and humid or super-humid remaining seasons.

Prior to leveling, the area was examined with an auger to check the occurrence and the distribution of soils in the area. Two $1.7 \mathrm{~m}$ deep pits were excavated in the gridded area for soil profile description and physico-chemical characterization. The soil of the area belongs to two taxonomic classes: Planossolo Háplico Eutrófico gleissólico and Gleissolo Háplico Ta Eutrófico solódico (Typic Albaqualf and Umbric Epiaqualf, respectively) according to Santos et al. (2006) and United States Department of Agriculture (2010), respectively, located on the relatively higher and lower portions of the area under study (Figure 1 A). The area had a depression in the central part due to a practically impermeable $\mathrm{B}$ horizon; consequently, the A horizon in the depression remained under saturated conditions during most part of the year (mainly winter), which is directly related to the formation of the Epiaqualf soil profile. 
The two soils do not present a sharp interface within the area. This situation is common in the rice growing lowland areas of the state of Rio Grande do Sul, Brazil. Before the start of the experiment, the area was cultivated twice with flood irrigated rice and lastly with grain sorghum, all under conventional tillage, which included plowing operations to the depth of about $0.20 \mathrm{~m}$. First, grid samples were collected after sorghum harvest, prior to land leveling, which occurred at the beginning of 2008 and was carried out with a laser ray controlled scraper, using a plano-altimetric survey and minimum squares approximation as described in Parfitt et al. (2004). The maximum cut was $0.21 \mathrm{~m}$ and the maximum fill was $0.17 \mathrm{~m}$ (Figure $1 \mathrm{~B}$ ). The final average
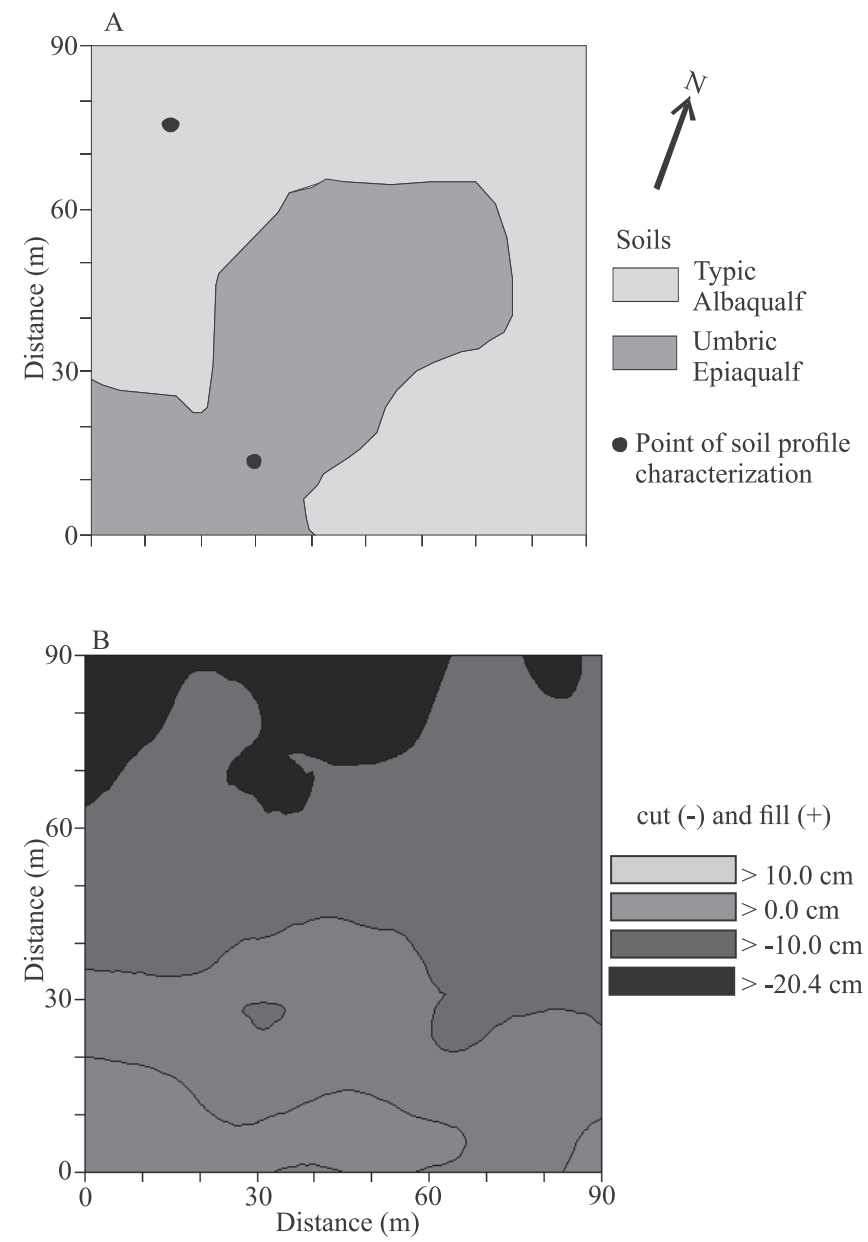

Figure 1. Spatial distribution of the soil in the experimental area and points of soil profile characterization (A); and topographic map of the depth of cuts and fills in the experimental area after leveling (B).

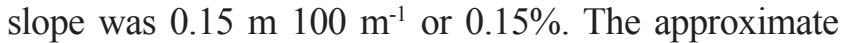
soil displacement was $519 \mathrm{~m}^{3} \mathrm{ha}^{-1}$, with about half of the area being cut and the other half being filled.

The land leveling operation (Figure $1 \mathrm{~B}$ ) consisted of cuts predominantly on the Typic Albaqualf and fills predominantly on the Umbric Epiaqualf. In other words, after leveling most of the collected soil samples from the $0-0.20 \mathrm{~m}$ layer were from the Albaqualf, including some material of the original $\mathrm{E}$ and $\mathrm{B}$ horizons (cut areas) and some of the A horizon (fill areas), since this soil was placed on top of the Epiaqualf(Figures $1 \mathrm{~A}$ and B). The characterization of the soil chemical attributes of the Typic Albaqualf soil profile before leveling is presented in Table 1.

The period between samplings before and after land leveling was three months. At each of the 100 georeferenced points, the mean values of clay, silt, and sand contents were determined according to Gee \& Bauder (1986) before and after leveling: 144 and $154 \mathrm{~g} \mathrm{~kg}^{-1}$ clay; 398 and $375 \mathrm{~g} \mathrm{~kg}^{-1}$ silt; and 458 and $471 \mathrm{~g} \mathrm{~kg}^{-1}$ sand, respectively, referring in both cases to a loam texture.

The following soil chemical attributes were evaluated according to the methodologies described in Tedesco et al. (1995): $\mathrm{pH}$ in water; the Shoemaker-MacLean-Pratt (SMP) index; potential acidity $(\mathrm{H}+\mathrm{Al})$ extracted with $0.5 \mathrm{molL}^{-1}$ calcium acetate solution; total soil $\mathrm{N}$ (TN) by the Kjeldahl method; available $\mathrm{P}$, and exchangeable $\mathrm{Na}$ and $\mathrm{K}$ extracted with $\mathrm{HCl} 0.05 \mathrm{~mol} \mathrm{~L}^{-1}+\mathrm{H}_{2} \mathrm{SO}_{4} 0.0125 \mathrm{~mol} \mathrm{~L}^{-1}$ solution (Mehlich-1); exchangeable $\mathrm{Ca}, \mathrm{Mg}$, and $\mathrm{Al}$, and available $\mathrm{Mn}$ extracted with $\mathrm{KCl} 1 \mathrm{~mol} \mathrm{~L}^{-1}$ solution; available $\mathrm{S}$ extracted with monocalcium phosphate $\left[\mathrm{Ca}\left(\mathrm{H}_{2} \mathrm{PO}_{4}\right)_{2}\right]$ solution (500 $\left.\mathrm{mg} \mathrm{L}^{-1} \mathrm{P}\right)$; available $\mathrm{B}$ extracted with hot water $\left(55 \pm 3^{\circ} \mathrm{C}\right)$; oxalate-extractable Fe (ammonium oxalate $0.2 \mathrm{~mol} \mathrm{~L}^{-1}, \mathrm{pH} \mathrm{3.0}$ ); available $\mathrm{Cu}$ and $\mathrm{Zn}$ extracted with $\mathrm{HCl} 0.1 \mathrm{~mol} \mathrm{~L}^{-1}$ solution; sum of bases (S) calculated by the sum of exchangeable $\mathrm{Ca}+\mathrm{Mg}+\mathrm{K}+\mathrm{Na}$; and cation exchange capacity (CEC at pH 7.0) calculated by the sum of $\mathrm{S}+\mathrm{H}+\mathrm{Al}$. Soil organic matter content (SOM) was calculated from soil organic carbon, which was determined by the Walkley-Black method (Claessen, 1997).

For the determination of the soil microbial biomass carbon (MBC), samples were collected with a screw auger in the same layer. The extracted soil was stored in a freezer until analysis. The MBC was determined according to the methodology described by Vance et al. 
(1987), in which chloroform is replaced by a microwave oven (for $4 \mathrm{~min}$ ) to eliminate microorganisms and release cell components, as recommended by Ferreira et al. (1999).

All data were subjected to descriptive statistical analysis and analyzed to confirm normality through the non-parametric Kolmogorov-Smirnov test, at 5\% probability, using the maximum distance $\mathrm{D}$ according to Webster \& Oliver (2007). To determine the overall effect of land leveling on all data sets, paired t tests were performed. For normal data distributions, the hypothesis of the applied test was parametric (t statistics) and for non-normal distributions, the test was non-parametric (Wilcoxon test) as in Ferreira (2005). To evaluate the effect of land leveling on the sampling variability of each attribute, the homogeneity of variance test (Ferreira, 2005) was applied using the methodology of Levene (1960) modified by Brown $\&$ Forsythe (1974). The analyses of linear regression were made using SAS, version 8.2 (SAS Institute, Cary, NC, USA).

\section{Results and Discussion}

According to Manual de adubação e de calagem para os Estados do Rio Grande do Sul e Santa Catarina (2004), the range and average values of all soil chemical attribute data before leveling are classified as follows: low to very low $\mathrm{pH}$ in water (Table 2); the range of SMP index values indicate lime amounts of 1.1 and $5.4 \mathrm{t} \mathrm{ha}^{-1}(100 \%$ PRNT) for soybean as an example; low average value of SOM $\left(21.0 \mathrm{~g} \mathrm{~kg}^{-1}\right)$ in the $0-0.20 \mathrm{~m}$ layer, which is important because it indicates nitrogen availability in the soil; CEC average value of $9.7 \mathrm{cmol}_{\mathrm{c}} \mathrm{dm}^{-3}$ within the middle range, classifying the range of exchangeable $\mathrm{K}$ contents (between 17 and $92 \mathrm{mg} \mathrm{dm}^{-3}$ ) from very low to medium, respectively; minimum and maximum values of 4.5 to $26.1 \mathrm{mg} \mathrm{dm}^{-3}$, respectively, for available $\mathrm{P}$ contents interpreted from medium to very high for irrigated rice crop; exchangeable Ca contents of 1.6 to $4.5 \mathrm{mg} \mathrm{dm}^{-3}$ from low to high; exchangeable $\mathrm{Mg}$ contents of 0.8 to $2.5 \mathrm{cmol}_{\mathrm{c}} \mathrm{dm}^{-3}$ and available $\mathrm{S}$ contents ranging from 8.7 to $35.2 \mathrm{mg} \mathrm{dm}^{-3}$, which are considered high values.

The average values of $\mathrm{Mn}, \mathrm{B}, \mathrm{Cu}$, and $\mathrm{Zn}$ are considered high, whereas the average value of $\mathrm{Fe}$ $\left(1,379 \mathrm{mg} \mathrm{dm}^{-3}\right)$ is within the low crystallinity range (995 to $1,737 \mathrm{mg} \mathrm{dm}^{-3}$ ), which is considered adequate. The average value of MBC was $297 \mathrm{mg} \mathrm{kg}^{-1}$ and is similar to that determined by Santos et al. (2004) in a crop rotation system experiment carried out with the same soil type.

The intense soil disturbance and transport during the leveling operation altered the majority of the soil chemical and biological attributes (Table 2). Only the mean values of $\mathrm{pH}\left(\mathrm{H}_{2} \mathrm{O}\right), \mathrm{B}$, and $\mathrm{Na}$ were not altered by the leveling operation in the paired comparison test, at $5 \%$ probability. The intense soil disturbance and transport during the leveling operation decreased significantly the average values of $\mathrm{H}+\mathrm{Al}, \mathrm{SOM}, \mathrm{TN}$, $\mathrm{P}, \mathrm{Ca}, \mathrm{Mg}, \mathrm{CEC}, \mathrm{S}, \mathrm{Fe}, \mathrm{Mn}$, and $\mathrm{Zn}$. Therefore, land leveling negatively affected soil fertility in the top $0.20 \mathrm{~m}$ layer, which can cause potentially negative effects on future crop productivity. Similar results were reported by Brye (2006) in a soil classified as Sharkey clay used for irrigated soybean and rice production in the Mississippi Delta region of northeast Arkansas, USA, where the contents of SOM, TN, P, and Mn

Table 1. Soil chemical attributes of the Planossolo Háplico Eutrófico gleissólico (Typic Albaqualf) soil profile in the experimental area before leveling ${ }^{(1)}$.

\begin{tabular}{|c|c|c|c|c|c|c|c|c|c|c|c|c|c|}
\hline \multirow{2}{*}{$\begin{array}{l}\text { Soil } \\
\text { horizon }\end{array}$} & \multirow[t]{2}{*}{ Soil depth } & \multirow{2}{*}{$\begin{array}{c}\mathrm{pH} \\
\left(\mathrm{H}_{2} \mathrm{O}\right)\end{array}$} & $\mathrm{Ca}$ & $\mathrm{Mg}$ & $\mathrm{S}$ & $\mathrm{Al}$ & $\mathrm{H}+\mathrm{Al}$ & $\mathrm{CEC}$ & $\mathrm{K}$ & $\mathrm{Na}$ & $\mathrm{Mn}$ & $\mathrm{P}$ & \multirow{2}{*}{$\begin{array}{c}\mathrm{SOM} \\
\left(\mathrm{g} \mathrm{kg}^{-1}\right)\end{array}$} \\
\hline & & & \multicolumn{6}{|c|}{ - } & \multicolumn{4}{|c|}{ - $\left(\mathrm{mg} \mathrm{kg}^{-1}\right)-1-1-$} & \\
\hline $\mathrm{A}$ & $0-20 / 33$ & 4.9 & 2.9 & 1.5 & 4.7 & 0.7 & 4.0 & 8.7 & 55 & 27 & 19.1 & 15.0 & 21.0 \\
\hline $\mathrm{AE}$ & $20 / 33-30 / 40$ & 4.6 & 1.2 & 1.0 & 2.4 & 1.5 & 3.4 & 5.8 & 16 & 41 & 4.8 & 2.4 & 6.1 \\
\hline E & $30 / 40-60 / 75$ & 4.8 & 1.5 & 1.4 & 3.2 & 1.3 & 3.0 & 6.2 & 16 & 61 & 1.2 & 0.9 & 2.9 \\
\hline $\mathrm{BE} / \mathrm{E}$ & $60 / 75-70 / 90$ & 4.8 & 3.6 & 3.5 & 7.7 & 2.1 & 4.3 & 12.1 & 35 & 130 & 1.8 & 1.4 & 5.0 \\
\hline B1 & $70 / 90-103 / 118$ & 4.9 & 4.7 & 4.8 & 10.3 & 1.7 & 4.0 & 14.2 & 47 & 151 & 1.2 & 1.4 & 3.8 \\
\hline B2 & $103 / 118-120 / 140$ & 5.1 & 4.8 & 4.8 & 10.4 & 1.1 & 3.1 & 13.5 & 51 & 153 & 3.3 & 1.2 & 2.1 \\
\hline $\mathrm{BC}$ & $20 / 140-160 / 170$ & 5.3 & 4.8 & 4.8 & 10.4 & 0.7 & 2.7 & 13.1 & 47 & 141 & 3.6 & 1.5 & 1.6 \\
\hline $\mathrm{C}$ & $160 / 170 \mathrm{~cm}+$ & 5.4 & 5.2 & 5.0 & 10.9 & 0.6 & 2.1 & 13.0 & 47 & 138 & 7.3 & 1.9 & 0.5 \\
\hline
\end{tabular}

${ }^{(1)} \mathrm{Ca}$, exchangeable calcium; $\mathrm{Mg}$, exchangeable magnesium; S, available sulfur; $\mathrm{Al}$, exchangeable aluminum; $\mathrm{H}+\mathrm{Al}$, potential acidity; $\mathrm{CEC}$, cation exchange capacity; K, exchangeable potassium; Na, exchangeable sodium; Mn, available manganese; P, available phosphorus; SOM, soil organic matter content.

Pesq. agropec. bras., Brasília, v.48, n.11, p.1489-1497, nov. 2013

DOI: 10.1590/S0100-204X2013001100010 
decreased and the contents of $\mathrm{K}$ and $\mathrm{Cu}$ increased as a result of the leveling operation. However, the means of $\mathrm{Ca}, \mathrm{Mg}, \mathrm{Na}, \mathrm{S}$, and Fe contents (Brye, 2006) changed in opposite directions as those observed in the present study.

In general, except for the average $\mathrm{K}$ content, these results can be explained by the fact that in cut areas there was an exposure of the Typic Albaqualf subsoil layers, which have a somewhat different chemical composition than the surface layer (Table 1). The exposure of these layers caused a decrease in the average contents of $\mathrm{Ca}, \mathrm{Mg}, \mathrm{Mn}$, and $\mathrm{SOM}$, and an increase in the average $\mathrm{Al}$ content. Assuming that the characterized soil profile adequately represents the general vertical and horizontal soil composition in the cut area, a change in the soil attributes after leveling should be expected (Table 2). Therefore, it is possible to foresee the behavior trend of the average content of the chemical attributes after leveling if the cut soil profile is previously known. Values of $\mathrm{Ca}, \mathrm{Mg}, \mathrm{S}, \mathrm{CEC}$, $\mathrm{Mn}, \mathrm{P}$, and SOM decreased in the soil profile, whereas Al increased; the same trend was observed with the average content after leveling.
The average MBC increased from 297 to $510 \mathrm{mg} \mathrm{kg}^{-1}$ as a result of the leveling operation, which can be attributed to the breakdown of larger aggregates caused by the severe disturbance of the soil, which, in turn, may have increased the soil microorganism population. However, land leveling resulted in $20 \%$ average decrease in SOM in the $0-0.20 \mathrm{~m}$ layer, which can represent a substantial loss of potential native soil fertility for crop production (Ramos \& Martínez-Casasnovas, 2006) and could contribute to global warming by depleting soil organic matter (Martínez-Casasnovas \& Ramos, 2009).

The average $\mathrm{K}$ content was the only attribute that did not behave as expected since it increased from $31 \mathrm{mg} \mathrm{dm}^{-3}$ before leveling to $38 \mathrm{mg} \mathrm{dm}^{-3}$ after leveling. Potassium can be present in larger contents in the soil due to the application of inorganic $\mathrm{K}$ fertilizers and, since potassium is a mobile cation in the soil, $\mathrm{K}$ would be expected to leach from the surface and accumulate in the subsoil. However, such behavior was not observed in the present study (Table 1). Brye et al. (2004) characterized the short-term impact of land leveling on the magnitude

Table 2. Descriptive statistics, Kolmogorov-Sminorv and variance homogeneity tests for chemical and biological attributes measured before and after land leveling operation with cuts predominantly on Typic Albaqualf and fills predominantly on Umbric Epiaqualf.

\begin{tabular}{|c|c|c|c|c|c|c|c|c|c|c|}
\hline \multirow[t]{2}{*}{ Attribute $^{(1)}$} & \multicolumn{2}{|c|}{ Mean } & \multicolumn{2}{|c|}{ Minimum value } & \multicolumn{2}{|c|}{ Maximum value } & \multicolumn{2}{|c|}{ Variance } & \multicolumn{2}{|c|}{$\mathrm{D}^{(2)}$} \\
\hline & Before & After & Before & After & Before & After & Before & After & Before & After \\
\hline $\mathrm{pH}\left(\mathrm{H}_{2} \mathrm{O}\right)$ & 4.9 & $4.9^{\mathrm{ns}}$ & 4.5 & 4.5 & 5.4 & 5.6 & 0.03 & $0.03^{\text {ns }}$ & $0.05^{\mathrm{N}}$ & $0.07^{\mathrm{N}}$ \\
\hline SMP index & 6.1 & $6.2 * * *$ & 5.6 & 5.6 & 6.5 & 6.6 & 0.03 & $0.02^{\mathrm{ns}}$ & $0.07^{\mathrm{N}}$ & $0.13^{\mathrm{NN}}$ \\
\hline $\mathrm{H}+\mathrm{Al}\left(\mathrm{cmol}_{\mathrm{c}} \mathrm{dm}^{-3}\right)$ & 4.6 & $4.1 * * *$ & 3.0 & 3.1 & 6.3 & 5.1 & 0.49 & $0.16^{* *}$ & $0.04^{\mathrm{N}}$ & $0.1^{\mathrm{NN}}$ \\
\hline $\operatorname{SOM}\left(\mathrm{g} \mathrm{kg}^{-1}\right)$ & 21 & $17 * * *$ & 17 & 9 & 26 & 21 & 3.0 & $7.7 * *$ & $0.8^{\mathrm{N}}$ & $1.3^{\mathrm{NN}}$ \\
\hline $\mathrm{TN}\left(\mathrm{mg} \mathrm{dm}^{-3}\right)$ & 1.4 & $1.3 * * *$ & 1.1 & 0.6 & 2.0 & 1.8 & 0.03 & $0.06^{* *}$ & $0.08^{\mathrm{N}}$ & $0.1^{\mathrm{NN}}$ \\
\hline $\mathrm{P}\left(\mathrm{mg} \mathrm{dm}^{-3}\right)$ & 12.5 & $8.3 * * *$ & 4.5 & 0.5 & 26.1 & 16.3 & 26.8 & $14.6^{\mathrm{ns}}$ & $0.1^{\mathrm{NN}}$ & $0.06^{\mathrm{N}}$ \\
\hline $\mathrm{Ca}\left(\mathrm{cmol}_{\mathrm{c}} \mathrm{dm}^{-3}\right)$ & 3.2 & $2.7 * * *$ & 1.6 & 1.5 & 4.5 & 3.7 & 0.36 & $0.26^{* *}$ & $0.14^{\mathrm{NN}}$ & $0.08^{\mathrm{N}}$ \\
\hline $\mathrm{K}\left(\mathrm{mg} \mathrm{dm}^{-3}\right)$ & 31 & $38 * * *$ & 17 & 18 & 92 & 64 & 179 & $144^{\mathrm{ns}}$ & $0.15^{\mathrm{NN}}$ & $0.13^{\mathrm{NN}}$ \\
\hline $\mathrm{Al}\left(\mathrm{cmol}_{\mathrm{c}} \mathrm{dm}^{-3}\right)$ & 0.6 & $0.8 * * *$ & 0.1 & 0.3 & 1.5 & 1.8 & 0.10 & $0.07^{\mathrm{ns}}$ & $0.16^{\mathrm{NN}}$ & $0.12^{\mathrm{NN}}$ \\
\hline $\mathrm{Mg}\left(\mathrm{cmol}_{\mathrm{c}} \mathrm{dm}^{-3}\right)$ & 1.6 & $1.1 * * *$ & 0.8 & 0.3 & 2.5 & 1.7 & 0.12 & $0.08^{\mathrm{ns}}$ & $0.12^{\mathrm{NN}}$ & $0.1^{\mathrm{NN}}$ \\
\hline $\mathrm{CEC}\left(\mathrm{cmol}_{\mathrm{c}} \mathrm{dm}^{-3}\right)$ & 9.7 & $8.2 * * *$ & 7.2 & 6.1 & 11.7 & 9.7 & 1.00 & $0.61^{\mathrm{ns}}$ & $0.08^{\mathrm{N}}$ & $0.08^{\mathrm{NN}}$ \\
\hline $\mathrm{S}\left(\mathrm{mg} \mathrm{dm}^{-3}\right)$ & 15.8 & $11.8 * * *$ & 8.7 & 5.8 & 35.2 & 17.1 & 17.89 & $6.55^{\mathrm{ns}}$ & $0.13^{\mathrm{NN}}$ & $0.07^{\mathrm{N}}$ \\
\hline $\mathrm{Fe}\left(\mathrm{mg} \mathrm{dm}^{-3}\right)$ & 1,379 & $1,242 * * *$ & 995 & 617 & 1,737 & 1,818 & 20.11 & $35.01^{\mathrm{ns}}$ & $0.1^{\mathrm{NN}}$ & $0.08^{\mathrm{N}}$ \\
\hline $\operatorname{Mn}\left(\mathrm{mg} \mathrm{dm}^{-3}\right)$ & 12.2 & $8.9 * * *$ & 4.9 & 1.8 & 21.6 & 18.0 & 14.67 & $8.94 *$ & $0.05^{\mathrm{N}}$ & $0.11^{\mathrm{NN}}$ \\
\hline $\mathrm{B}\left(\mathrm{mg} \mathrm{dm}^{-3}\right)$ & 0.9 & $0.9^{\text {ns }}$ & 0.7 & 0.4 & 1.1 & 1.8 & 0.01 & $0.08 * *$ & $0.08^{\mathrm{N}}$ & $0.06^{\mathrm{N}}$ \\
\hline $\mathrm{Cu}\left(\mathrm{mg} \mathrm{dm}^{-3}\right)$ & 1.3 & $1.3^{\mathrm{ns}}$ & 0.8 & 0.7 & 1.8 & 3.7 & 0.05 & $0.23^{\mathrm{ns}}$ & $0.14^{\mathrm{NN}}$ & $0.23^{\mathrm{NN}}$ \\
\hline $\mathrm{Zn}\left(\mathrm{mg} \mathrm{dm}{ }^{-3}\right)$ & 1.1 & $0.7 * * *$ & 0.3 & 0.1 & 2.7 & 2.0 & 0.28 & $0.10 * *$ & $0.13^{\mathrm{NN}}$ & $0.12^{\mathrm{NN}}$ \\
\hline $\mathrm{Na}\left(\mathrm{mg} \mathrm{dm}^{-3}\right)$ & 52 & $50^{\mathrm{ns}}$ & 21 & 30 & 90 & 113 & 224 & $147 *$ & $0.08^{\mathrm{N}}$ & $0.15^{\mathrm{NN}}$ \\
\hline $\mathrm{MBC}\left(\mathrm{mg} \mathrm{kg}^{-1}\right)$ & 297 & $510 * * *$ & 118 & 290 & 527 & 802 & 6,841 & $14,857 * *$ & $0.11^{\mathrm{NN}}$ & $0.06^{\mathrm{N}}$ \\
\hline
\end{tabular}

${ }^{(1)} \mathrm{TN}$, total nitrogen; CEC, cation exchange capacity; MBC, microbial biomass carbon. ${ }^{(2)}$ Value of the Kolmogorov-Smirnov statistical test. ${ }^{\mathrm{N}}$ Normal

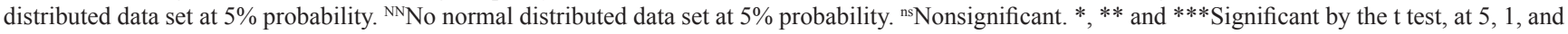
$0.1 \%$ probability, respectively, applied to mean values of each attribute before and after land leveling. 
of soil chemical attributes in an Albaqualtic Hapludalf in eastern Arkansas, USA, and also verified an increase in the $\mathrm{K}^{+}$content after leveling. The authors attributed this behavior to the presence of certain clay minerals, such as illite, particularly in subsoil with an argillic horizon. A similar effect could also be attributed to the soils in the present study since Castilhos \& Meurer (2002) found micas in the clay fraction of the argillic horizon of a similar Albaqualf collected in the same region.
The variance parity test of Levene (1960), modified by Brown \& Forsythe (1974), applied to the variable sets before and after leveling, showed that the variances for $\mathrm{pH}\left(\mathrm{H}_{2} \mathrm{O}\right)$, SMP index, $\mathrm{P}, \mathrm{K}, \mathrm{Al}$, $\mathrm{Mg}, \mathrm{CEC}, \mathrm{S}, \mathrm{Fe}$, and $\mathrm{Cu}$ did not change significantly (Table 2). However, land leveling significantly changed the variance values for the other nine soil properties evaluated.

The great majority of the chemical attributes did not show relations between their values and the magnitude
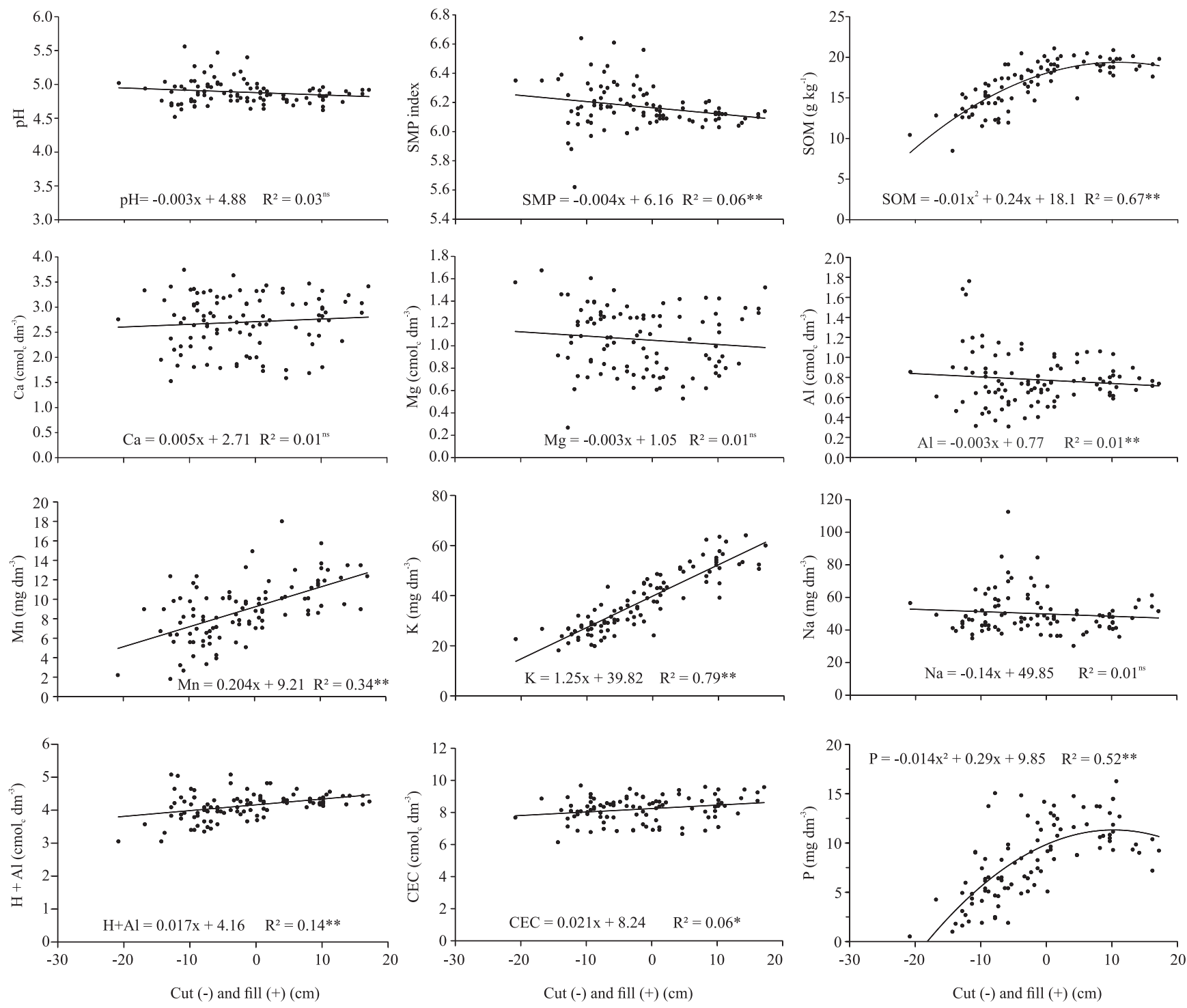

Figure 2. Regressions between cut (-) and fill ( + ) depths and $\mathrm{pH}\left(\mathrm{H}_{2} \mathrm{O}\right)$, SMP index, soil organic matter (SOM), calcium $(\mathrm{Ca})$, magnesium $(\mathrm{Mg})$, aluminum $(\mathrm{Al})$, manganese $(\mathrm{Mn})$, potassium $(\mathrm{K})$, sodium $(\mathrm{Na})$, potential acidity $(\mathrm{H}+\mathrm{Al})$, cation exchange capacity $(\mathrm{CEC})$, and phosphorus $(\mathrm{P})$, as well as equations and respective coefficients of determination. ${ }^{\text {ns Nonsignificant. } * \text { and }}$ **Significant by the $\mathrm{t}$ test at 5 and $1 \%$ probability, respectively. 
of cuts and fills (Figures 2 and 3 ). This can be observed by the low coefficients of determination $\left(\mathrm{R}^{2}\right)$, although significant. The significant values of the regressions are related to the large number of samples, since, according to Charnet et al. (1999), increments in sample number increase the possibility of significance of the $\mathrm{R}^{2}$, even without a satisfactory relation between the variables. However, the $\mathrm{R}^{2}$ values, besides significant, were greater than 0.5 for SOM, K, P (Figure 2), and TN (Figure 3). The relation was quadratic for SOM, P, and $\mathrm{TN}$, indicating increase of these attributes in cut areas and stability in fill areas.

Statistically significant relationships between soil chemical attributes and the magnitude of cuts and fills after leveling have potential to be used as a basis for future soil management projects. They open the possibility to improve soil fertility by applying inorganic and organic fertilizers in a more rational way to obtain higher productivity of crops to be introduced in recently leveled land. The correlations between these attributes and the depths of cuts and fills suggest that the cut and fill map (Figure 1 B) could be used by farmers as a practical tool for the production system, i.e., in the case of potassium (Figure 2), the greater the cut depth, the greater the need of a supplementation of this nutrient. For SOM (Figure 2), the application of N would be homogeneous in the fill areas. In this way, the application of a given nutrient could be made taking into account the homogeneity of the cut zones. The linear regression for $\mathrm{MBC}$ and the magnitude of cuts and fills (Figure 3) show a positive slope that indicates lower MBC in cut areas. In other words, there was an increase in soil microorganism populations in filled areas after leveling.
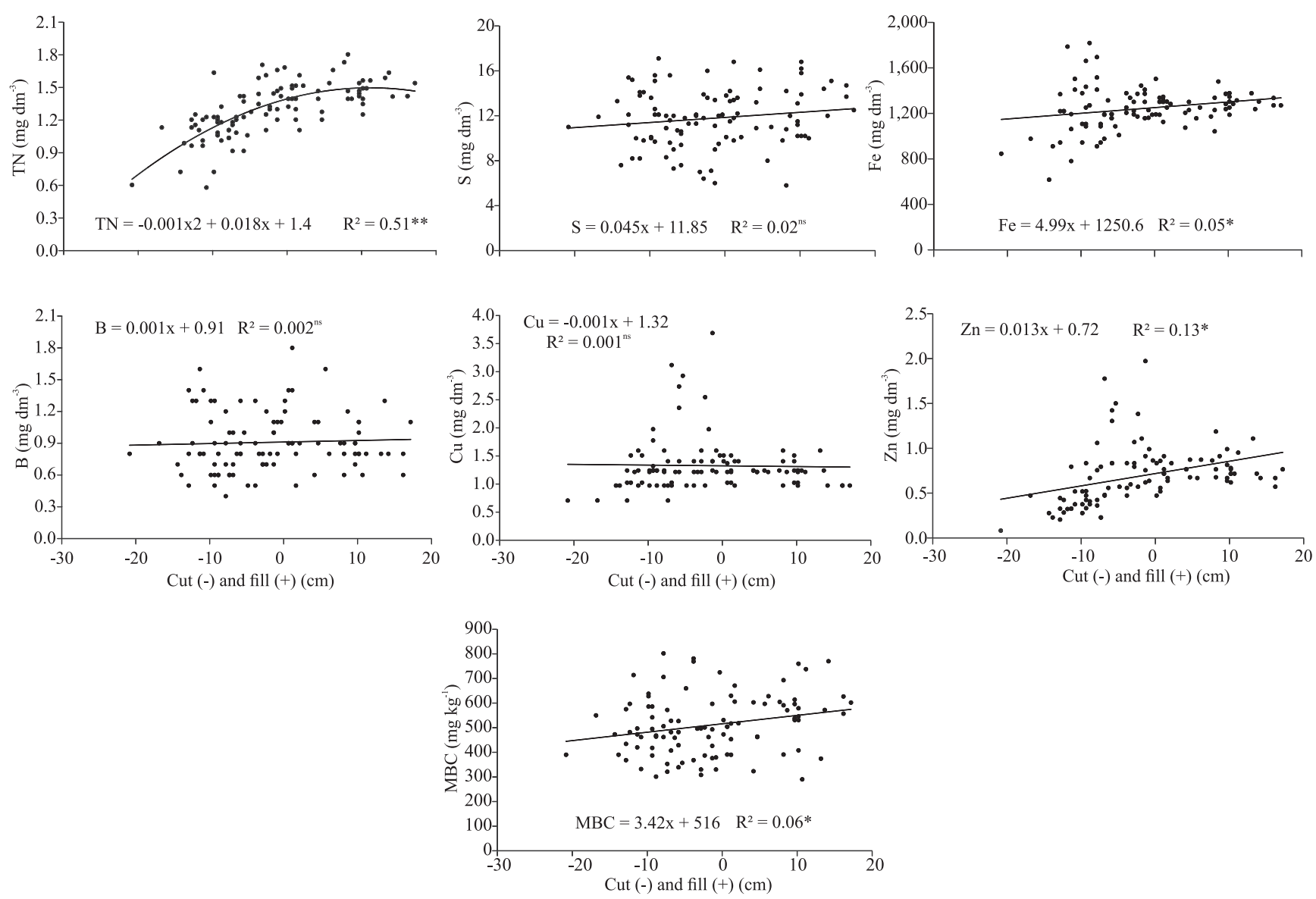

Figure 3. Regressions between cut (-) and fill (+) depths and soil total nitrogen (TN), sulfur (S), iron (Fe), boron (B), copper $(\mathrm{Cu})$, zinc $(\mathrm{Zn})$, and soil microbial biomass carbon $(\mathrm{MBC})$, as well as equations and respective coefficients of determination. ${ }^{n s}$ Nonsignificant. * and $* *$ Significant by the t test at 5 and $1 \%$ probability, respectively. 


\section{Conclusions}

1. Land leveling operations alter the magnitude of soil chemical and biological attributes.

2. The changes in the values of soil chemical attributes are related to the characteristics of the soil profile of cut areas.

3. The relationships between chemical attributes and the magnitudes of cuts and fills indicate that land leveling map may be a useful tool for degraded soil recuperation through amendments and organic fertilizers.

\section{Acknowledgments}

To Embrapa Clima Temperado, for field support; to Conselho Nacional de Desenvolvimento Científico e Tecnológico (CNPq) and to Coordenação de Aperfeiçoamento de Pessoal de Nível Superior (Capes), for funding and scholarships granted.

\section{References}

BROWN, M.B.; FORSYTHE, A.B. Robust tests for equality of variances. Journal of the American Statistical Association, v.69, p.364-367, 1974. DOI: 10.1080/01621459.1974.10482955.

BRYE, K.R. Soil biochemical properties as affected by land leveling in a Clayey Aquert. Soil Science Society of America Journal, v.70, p.1129-1139, 2006. DOI: 10.2136/sssaj2005.0348.

BRYE, K.R.; SLATON, N.A.; MOZAFFARI, M.; SAVIN, M.C.; NORMAN, R.J.; MILLER, D.M. Short-term effects of land leveling on soil chemical properties and their relationships with microbial biomass. Soil Science Society of America Journal, v.68, p.924-934, 2004. DOI: 10.2136/sssaj2004.0924.

BRYE, K.R.; SLATON, N.A.; NORMAN, R.J. Penetration resistance as affected by shallow-cut land leveling and cropping. Soil and Tillage Research, v.81, p.1-13, 2005. DOI: 10.1016/j. still.2004.03.019.

CASTILHOS, R.M.V.; MEURER, E.J. Suprimento de potássio de solos do Rio Grande do Sul para arroz irrigado por alagamento. Revista Brasileira de Ciência do Solo, v.26, p.977-982, 2002.

CAY, E.R.; CATTLE, S.R. The effects of landforming on soil profile characteristics of an irrigated cotton-producing area of southeastern Australia. Soil and Tillage Research, v.84, p.76-86, 2005. DOI: 10.1016/j.still.2004.09.019.

CENSO da lavoura de arroz irrigado do Rio Grande do Sul - safra 2004/05. Porto Alegre: IRGA, 2006. 122p.

CHARNET, R.; BONVINO, H.; FREIRE, C.A. de L.; CHARNET, E.M.R. Análise de modelos de regressão linear: com aplicações. Campinas: Unicamp, 1999. 354p.
CLAESSEN, M.E.C. (Org.). Manual de métodos de análise de solo. 2.ed. rev. atual. Rio de Janeiro: Embrapa-CNPS, 1997. 212p. (Embrapa-CNPS. Documentos, 1).

FERREIRA, A.S.; CAMARGO, F.A.; VIDOR, C. Use of microwave radiation to evaluate soil microbial biomass. Revista Brasileira de Ciência do Solo, v.23, p.991-996, 1999.

FERREIRA, D.F. Estatística básica. Lavras: Ed. da UFLA, 2005. $664 p$.

GEE, G.W.; BAUDER, J.W. Particles size analysis. In: KLUTE, A. (Ed.). Methods of soil analysis. Part 1. Physical and mineralogical methods. $2^{\text {nd }}$ ed. Madison: American Society of Agronomy: Soil Science Society of America, 1986. p.383-411.

KÖPPEN, W. Grundriss der Klimakunde. Leipzig: Walter de Gruyter, 1931. 388p.

LEVENE, H. Robust test for equality of variances. In: OLKIN, I.; GHURYE, S.G.; HOEFFDING, W.; MADOW, W.G.; MANN, H.B. (Ed.). Contribution to probability and statistics. Stanford: Stanford University, 1960. p.278-292.

MANUAL de adubação e de calagem para os Estados do Rio Grande do Sul e Santa Catarina. 10.ed. Porto Alegre: Sociedade Brasileira de Ciência do Solo - Núcleo Regional Sul - Comissão de Química e Fertilidade do Solo, 2004. 400p.

MARTÍNEZ-CASASNOVAS, J.A.; RAMOS, M.C. Soil alteration due to erosion, ploughing and levelling of vineyards in North east Spain. Soil Use and Management, v.25, p.183-192, 2009. DOI: 10.1111/j.1475-2743.2009.00215.x.

PARFITT, J.M.B.; SILVA, C.A.S.; PETRINI, J.A. Estruturação e sistematização da lavoura de arroz irrigado. In: GOMES, A. da S.; MAGAlHÃES JUNIOR, A.M. (Ed.). Arroz irrigado no Sul do Brasil. Pelotas: Embrapa Clima Temperado; Brasília: Embrapa Informação Tecnológica, 2004. p.237-257.

PINTO, L.F.S.; LAUS NETO, J.A.; PAULETTO, E.A. Solos de várzea do Sul do Brasil cultivados com arroz irrigado. In: GOMES, A. da S.; MAGALHÃES JUNIOR, A.M. de (Ed.). Arroz irrigado no Sul do Brasil. Pelotas: Embrapa Clima Temperado; Brasília: Embrapa Informação Tecnológica, 2004. p.75-95.

RAMOS, M.C.; COTS-FOLCH, R.; MARTÍNEZ-CASASNOVAS, J.A. Effects of land terracing on soil properties in the Priorat region in Northeastern Spain: a multivariate analysis. Geoderma, v.142, p.251-261, 2007. DOI: 10.1016/j.geoderma.2007.08.005.

RAMOS, M.C.; MARTÍNEZ-CASASNOVAS, J.A. Impact of land leveling on soil moisture and runoff variability in vineyards under different rainfall distributions in a Mediterranean climate and its influence on crop productivity. Journal of Hydrology, v.321, p.131-146, 2006. DOI: 10.1016/j.jhydrol.2005.07.055.

RAMOS, M.C.; MARTÍNEZ-CASASNOVAS, J.A. Soil water balance in rainfed vineyards of the Penedès region (Northeastern Spain) affected by rainfall characteristics and land leveling: influence on grape yield. Plant and Soil, v.333, p.375-389, 2010. DOI: $10.1007 / \mathrm{s} 11104-010-0353-y$.

REICHERT, J.M.; DARIVA, T.A.; REINERT, D.J.; SILVA, V.R. da. Variabilidade espacial de Planossolo e produtividade de soja em várzea sistematizada: análise geoestatística e análise de 
regressão. Ciência Rural, v.38, p.981-988, 2008. DOI: 10.1590/ S0103-84782008000400012.

SANTOS, H.G. dos; JACOMINE, P.K.T.; ANJOS, L.H.C. dos; OLIVEIRA, V.A. de; OLIVEIRA, J.B. de; COELHO, M.R.; LUMBRERAS, J.F.; CUNHA, T.J.F. (Ed.). Sistema brasileiro de classificação de solos. 2.ed. Rio de Janeiro: Embrapa Solos, 2006. $306 \mathrm{p}$.

SANTOS, V.B. dos; CASTILHOS, D.D.; CASTILHOS, R.M.V.; PAULETTO, E.A.; GOMES, A. da S.; SILVA, D.G. da. Biomassa, atividade microbiana e teores de carbono e nitrogênio totais de um Planossolo sob diferentes sistemas de manejo. Revista Brasileira de Agrociência, v.10, p.333-338, 2004.

TEDESCO, M.J.; GIANELLO, C.; BISSANI, C.A.; BOHMEN, H.; VOLKWEISS, S.J. Análises de solo, plantas e outros materiais. 2.ed. Porto Alegre: UFRGS, 1995. 174p.
UNITED STATES DEPARTMENT OF AGRICULTURE. Natural Resources Conservation Service. Keys to soil taxonomy. $11^{\text {th }}$ ed. 2010. Washington: USDA, 2010. 346p.

VANCE, E.D.; BROOKES, P.C.; JENKINSON, D.S. An extraction method for measuring soil microbial biomass C. Soil Biology and Biochemistry, v.19, p.703-707, 1987. DOI: 10.1016/0038-0717(87)90052-6.

WALKER, T.W.; KINGERY, W.L.; STREET, J.E.; COX, M.S.; OLDHAM, J.L.; GERARD, P.D.; HAN, F.X. Rice yield and soil chemical properties as affected by precision land leveling in Alluvial soils. Agronomy Journal, v.95, p.1483-1488, 2003. DOI: 10.2134/agronj2003.1483.

WEBSTER, R.; OLIVER, M.A. Geostatistics for environmental scientists. $2^{\text {nd }}$ ed. Chichester: J. Wiley, 2007. 325p. DOI: 10.1002/9780470517277.

Received on November 12, 2012 and accepted on October 30, 2013 